\title{
1968 AS A SYMBOL
}

\section{Introduction}

T he year 1968 keeps capturing collective imagination on both sides of the Atlantic, as it serves as a convenient shortcut for social developments and upheavals throughout the 1960 s. Even though in every country the events of 1968 unfolded differently, dramatic street protests demanding profound social changes define the dominant memory of this year on global scale. Violent suppression of street protesters by security forces form the dominant images of that year all around the globe, even if targets of the popular discontent were quite diverse.

The year 1968 can also be seen as the pinnacle of idealistic efforts for progressive social change, which was replaced by normalization efforts induced by various methods in different contexts throughout the 1970s. As such, it is connected with feelings of nostalgia and lost opportunities especially for those who consider themselves to be progressives. But to what extent were the events of 1968 truly seminal? What were their lasting legacies?

The 50th anniversary called for critical reappraisal of the various legacies stemming from 1968. The following special issue highlights various transnational legacies of 1968 as they were presented at an academic symposium in Prague in May 2018. The symposium itself was a commemorative academic event that produced new knowledge and insights related to the topic. Such academic commemorations are useful as they reveal what specific topics resonate in connection with the original theme even after 50 years. The special issue is thus by itself a relevant document on the academic legacies of 1968.
Kryštof Kozák Charles University Prague Czech Republic Guest Editor

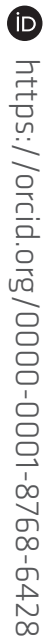


This collection of essays approaches the multi-faceted legacies of १९६८ from various interdisciplinary perspectives. Jan Céryk focuses on US far-left reactions to the events in Czechoslovakia in 1968 in order to highlight the schism that Warsaw pact invasion caused in the US György Tóth makes the case for a more broadly perceived Native American 1968 and explores its transnational legacy. Adrian Matus explores the idea of widespread Eastern-European 1968, again highlighting various transnational linkages of the process. Alexander Gungov takes a look at the political journey of the 1968 generation by analyzing Paul Berman's A Tale of Two Utopias, thereby underlining the legacy on the individual level.

Nicola Paladin uses the novel The Nix by Nathan Hill and looks at the modes of protest, thus linking it to methods used in 1968. Albena Bakratcheva's essay complements it by discussing Henry Thoreau's work on civil disobedience and explores its usage both in 1968 and after. Both roots and legacies of 1968 come under scrutiny in Alessandro Buffa s contribution that focuses on the role of music, especially blues in transnational context. The special issue ends symbolically with Marie Černá, who works primarily with the memory of the Warsaw Pact intervention and highlights the processes of manipulation, oblivion and conservation.

Taken as a whole, the special issue confirms the existence of numerous transnational linkages that were crucial in the social dynamics under scrutiny. Such findings are valuable for our understanding of transnational ties to this day. The issue also attests to the complex legacies of 1968 that resonate to this day, as the year 1968 keeps being regarded as an important symbol of mass mobilization for social change.

Kryštof Kozák

RIAS Cuest Editor 